\title{
Resilience to hazards: rice farmers in the Mahanadi Delta, India
}

\author{
$\underline{\text { John M. Duncan }}^{1}$, Emma L. Tompkins $^{2}, \underline{\text { Jadunandan Dash }}^{3}$ and Basundhara Tripathy $^{4}$
}

\begin{abstract}
Developing country deltas are important food producing areas and are home to large numbers of subsistence farmers. In particular, rice farmers dominate the populous deltas of South and Southeast Asia and face frequent climate hazards that have short- and long-term impacts on rice production and livelihoods. The aim of this study is to identify and explain proximal and ultimate factors (land access, cultural practices, and institutional support) that affect rice farmer resilience, that is, to explain why some farmers are more sensitive to climate shocks, why some farmers suffer long-term impacts from climate shocks, and what underlying "ultimate" factors reproduce this vulnerability over time. We undertake this analysis using qualitative interviews and household survey data from two districts in the Mahanadi Delta, Odisha, India. We show that climate hazards cause rice production shocks that are problematic for farmers because rice is predominantly used for household consumption in a context of unreliable off-farm income sources and a lack of insurance and credit. Our research emphasizes that "ultimate" drivers interact with the current mode of rice cultivation to reproduce a low resilience farming state. We argue that agricultural development interventions seeking to make rice farming more resilient to climate hazards should focus on boosting productivity and shock-resistance, but also be cognizant of the system within which rice farming is practiced and the contextual "ultimate" factors that reproduce vulnerability.
\end{abstract}

Key Words: climate shocks; deltas; resilience; rice farming

\section{INTRODUCTION}

Globally, deltas are home to around 500 million people (Giosan et al. 2014). They generate significant rice, fish, shrimp, and other agricultural outputs (Chu et al. 2010). They perform important ecological services, such as fish nurseries, which support marine fisheries globally, storm buffering, and absorption of nutrients and sediments, which if discharged directly in the oceans cause algal blooms and oxygen-dead zones (Vörösmarty et al. 2009). Yet deltas are highly vulnerable to climate hazards (Ericson et al. 2006). Many of those resident in developing country deltas have mixed livelihoods based on rice or shrimp farming and fishing, and are highly susceptible to hazard impacts, yet we know little about what makes these farmers resilient to impacts. As a geographical unit, despite their economic and ecosystem service value, deltas and their populations are underresearched (Wassmann et al. 2004).

Climate hazards affect agriculture through both short- and longterm adverse impacts on economic growth and human well-being (Hoddinott 2006, Carter et al. 2007, Barrett and Santos 2014, Hsiang and Jina 2014). These impacts are heterogeneous; some groups, e.g. households, communities, or countries, face higher probabilities of exposure, some are better able to resist shocks, and some are better able to recover. At the same time, hazard impacts on agriculture can reinforce poverty traps, and heighten risk. In the absence of markets for insurance and credit, these impacts can lead farmers to choose low-return agricultural technologies to maintain stable livelihoods, often at levels below the poverty line (Carter et al. 2007, Dercon and Christiaensen 2011, Barrett et al. 2015). Repeated exposure to climate hazards can undermine current and future coping capacity (Béné et al. 2016a, Duncan et al. 2017). In this context of growing awareness of the damaging interaction between climate hazards, response and coping capacity, and short- and long-term growth, the policy of "resilience building" has emerged as a possible antidote. Its prevalence is increasing in development discourses and policy (DFID 2011).

Climate hazards affect subsistence farmers in deltas through frequent floods, droughts, and storm surges with subsequent impacts on food production. Rice is the staple cereal crop in many deltas and is a major constituent of livelihoods. Rice cropping is sensitive to losses following climate hazards (Krishna Kumar et al. 2004, Birthal et al. 2015). Data from a randomized controlled trial (RCT) in the Mahanadi Delta, Odisha (a coastal state in Northeast India; Fig. 1), shows that commonly cultivated rice varieties suffer a $45 \%$ yield loss relative to flood-tolerant varieties when farms are exposed to submergence for 10 days (Dar et al. 2013). Similarly, in Bangladesh, climate hazards are a significant cause of income volatility for rice farmers (Mottaleb et al. 2013). There is also evidence that climate hazards have long-term consequences; tropical cyclone shocks to rice farmers in Bangladesh reduced spending on education (Mottaleb et al. 2013) and the 1999 super cyclone in Odisha left coastal fields too saline for rice cropping with livelihoods not recovering a decade later (Chhotray and Few 2012).

Enhancing rice farming resilience to climate hazards is an important objective. The challenge is amplified by the magnitude of climate hazard exposure in deltas, and the concentrations of poor households who practice rice cultivation in deltas. It is likely that climate change will increase the intensity and occurrence of climate hazards (Mathison et al. 2013). Without understanding how to build the resilience of rice farming in deltas, it is difficult to create effective long-term management plans for agricultural development, and to assess the consequences of future climate change on rice production, and on farmer livelihoods. Here, to address this issue, we use primary field data from the Mahanadi Delta in India to assess what factors explain rice farmer resilience to climate hazards.

${ }^{1}$ UWA School of Agriculture and Environment, University of Western Australia, ${ }^{2}$ Geography and Environment, University of Southampton, UK, ${ }^{3}$ Geography and Environment, University of Southampton, UK., ${ }^{4}$ Wageningen School of Social Sciences (WASS), Wageningen University and Research 
Fig. 1. Map depicting the location of Jagatsinghpur and Kendrapara districts across the Mahanadi Delta, Odisha, where villages were sampled for household surveys and semistructured interviews. Background imagery is obtained from Landsat TM5 imagery from October 2009.

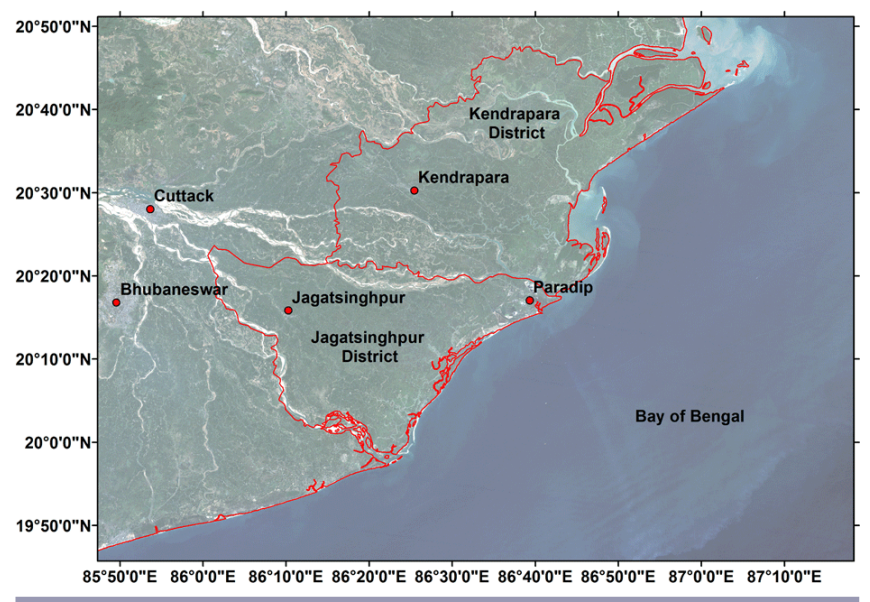

In the Mahanadi Delta the majority of farmers are smallholders excluded from local economic growth (Ministry of Agriculture $2014 a$ ). Odisha is one of India's poorest states with high levels of food insecurity (Pritchard et al. 2013, Ministry of Statistics and Programme Implementation 2014). Rice farmers are exposed to frequent climate hazards, typically tropical cyclones and floods alongside a diverse range of environmental, social, political, and economic stresses (Chhotray and Few 2012, Das 2012, Chhotray et al. 2013), making it relatively typical of developing country deltas. Rice farming in Odisha is pursued on its own, or as part of a mix of livelihood strategies under a range of owned land and share cropping arrangements. This context enables assessment of how climate hazards interact with different rice farming livelihood strategies to determine resilience.

In this paper we identify the following: (i) the short- and longterm impact of climate hazards on rice farming, (ii) which livelihood strategies face greater risk and are susceptible to adverse impacts, (iii) what short-term coping strategies rice farmers employ, and (iv) what are the contextual factors that maintain or reduce vulnerability. We identify contextual drivers of resilience that ultimately explain heterogeneity in the shortterm impacts and explain why, for some farmers, rice cropping remains a risky activity over time that does not support resilience building.

\section{RESILIENCE TO CLIMATE HAZARDS IN DELTAS}

Central to the notion of resilience is the ability of a system to absorb shocks or stresses while maintaining existing structure and function (Folke 2006). In ecology, resilience is the degree to which a system can adapt, learn, and self-organize (Walker et al. 2004). Resilience to disasters is the ability to manage change, by maintaining or transforming living standards in the face of shocks without compromising long-term prospects (DFID 2011). Recognizing the strength of resilience as a concept to guide understanding of system response to change and exogenous shocks, researchers and policy makers are utilizing the concept to address development challenges (Barrett and Constas 2014, Béné et al. 2016b). In this context, the concept of resilience has been adapted to be cognizant of issues such as marginality, power, and agency and associated social and institutional structures that the vulnerability literature has flagged as being important to explain differential susceptibility to harm (Béné et al. 2012, 2014, Tanner et al. 2015). Recent definitions of resilience, adopted herein, describe it as a capacity, possessed by a unit, e.g. household, community, or country, to maintain or improve standards of living while facing an uncertain risk landscape (Barrett and Constas 2014).

In order to implement agricultural development policy in deltas that builds farmer resilience, we first need to be able to assess the conditions that create resilience. Increasingly, it is recognized that resilience assessments have two essential components. The first identifies the characteristics of farmers that explain heterogeneous responses to shocks (Carter et al. 2007, Hoddinott and Quisumbing 2010). The second identifies the social, economic, and institutional factors that create feedbacks reproducing this differential response capacity (Bahadur et al. 2013, Béné et al. 2016a). The first of these assessment components identifies "proximal" factors that affect or predict the resilience of rice farmers to climate hazards. Knowledge of these proximal factors is important for targeting within agricultural development policy ensuring the resilience of vulnerable groups of farmers is bolstered.

The second of these resilience assessment components identifies contextual drivers of resilience. These are the underlying social, institutional, and economic factors that generate feedbacks determining the distribution of proximal factors and the observed heterogeneity in resilience. The vulnerability literature emphasizes the importance of contextual factors in determining the differential impacts of natural hazards, most notably referred to as "root causes" within the pressure and release model (Wisner et al. 2004). Within a resilience framing, contextual drivers of resilience interact with proximal factors, as well as contemporary characteristics of the farming system generating feedbacks that create path-dependency in the trajectory of farm resilience. This is exemplified by Enfors (2013) and Enfors and Gordon (2008) who use evidence from drought prone catchments in Tanzania to show that institutional change, drought, and population growth reinforce a cycle of ecosystem degradation, low crop yields, and poverty. They argue that destabilization of these feedbacks is necessary for alternative development trajectories to take place. Awareness of ultimate contextual, social, and institutional factors is important for realizing sustained impact from social protection interventions; this is encapsulated in the concept of transformative social protection (Sabates-Wheeler and Devereux 2011). Béné et al. (2012) draws upon this to argue that awareness of these same factors are important for building resilience to shocks (among certain groups). Inclusive and effective institutions, social capital, and equity have been reported as key characteristics of climate resilient systems (Bahadur et al. 2013).

Without addressing contextual factors, and the associated feedbacks, that give rise to "domains of attraction" (Scheffer et al. 2001) or "multiple equilibria" (Carter and Barrett 2006) agricultural policy interventions that target only proximal factors will not have a long-term impact and risk reinforcing a low resilience state ${ }^{[1]}$. In the long-run, and in the absence of other shocks, rice farmers will return back to their initial state of 
resilience unless contextual factors are given due attention. Here, we assess both the proximal factors and contextual drivers of resilient rice farming in the Mahanadi Delta. This research supplements a growing literature that provides empirical evidence on proximal and contextual factors that shape the resilience of farming communities facing an intensifying climate risk landscape (Enfors and Gordon 2008, Béné et al. 2011, 2016a, Enfors 2013, Rufino et al. 2013, Robinson et al. 2015).

\section{METHODS TO ASSESS CLIMATE RESILIENCE OF SUBSISTENCE RICE FARMERS IN THE MAHANADI DELTA}

A mixed methods approach was adopted in this study, comprising household surveys, semistructured interviews, and focus groups, all of which were undertaken in the Mahanadi Delta districts of Jagatsinghpur and Kendrapara, Odisha (Fig. 1) between October 2014 and December 2014. The Mahanadi Delta was selected because it has a dense and growing population that is reliant upon subsistence agriculture, facing pressure over available land for farming, and frequently impacted by climate hazards. We specifically targeted Jagatsinghpur and Kendrapara districts because they span the majority of the delta's extent and are the sites of recent hazard impacts including the 1999 Super Cyclone, Cyclone Phailin in 2013, and floods in 2008.

In Jagatsinghpur, $81 \%$ of operational holdings were less than 1 ha as reported in the 2010-2011 Agricultural Census; in Kendrapara, $74 \%$ of operational holdings were less than 1 ha (Ministry of Agriculture 2014b). In Jagatsinghpur, $69 \%$ of operational holdings were owned and self-operated; in Kendrapara, this value was $65 \%$ (Ministry of Agriculture 2014b). In 2014-2015, 34\% of the rice area cultivated was irrigated in Kendrapara; this same statistic was $69 \%$ in Jagatsinghpur (DES 2013) ${ }^{[2]}$. We conducted a household survey of 300 randomly sampled households that was representative of this small-scale rice farming population (see Appendix 1).

Data were collected by a UK-based researcher, supported by a team of three Indian enumerators who conducted the household surveys, and one Indian research assistant who provided translation support and formal access to villages. Household surveys were used to identify the following: (i) the differential impacts of climate hazards (floods and cyclones) on rice cropping across socioeconomic groups; (ii) how rice farming households cope with shortfalls in rice cropping in normal years and in times of disaster, and what are the longer term implications of these coping strategies. Semistructured interviews with rice farmers were used to identify (iii) the underlying contextual factors that led to rice famers' resilience or persistent vulnerability. Focus groups were used to validate the data collected.

Household survey data was collected on household livelihood strategies, land ownership, cropping practices, climate hazard impacts, coping and adaptive strategies, and access to institutional support. The household survey collected data from a random sample of rice farming households impacted by the 2008 floods. Households from 10 villages were sampled exceeding the sample size required to maintain a $10 \%$ margin of error at a $95 \%$ confidence level (accounting for a design effect of two, and a 10\% no-response rate; see Appendix 1). The 10 villages were selected using the probability proportionate to size method using the 2011 census as a sampling frame (Government of India 2011). Within each village a random start point was selected using high resolution satellite imagery and enumerators surveyed households following a random walk from this point.
The household survey data was analyzed using descriptive statistics and random effects models that accounted for within-village correlation. Response variables in the household survey were categorical, either binary or ordinal, because of issues related to respondents' memory recall. For example, farmers were able to provide responses within broad percentage ranges (e.g., 50-75\% of harvest lost due to 2008 floods; normally sell 0 " $50 \%$ of rice harvested). For nonrecall data, e.g., area of land owned, we collected continuous variables.

Given the categorical response variables, analysis of the household survey data was conducted using random effects binary logit models or random effects ordered logit models. The random effects models account for the multilevel data structure with sampled households clustered in villages. Households clustered in villages are likely to be more similar violating assumptions of independence (Günther and Harttgen 2009); the use of multilevel models allows for clustering while providing correct standard errors and significance tests. The random effects binary logit models take the following form:

$$
y_{i j}=\beta_{0}+\beta_{1} x_{i j}+u_{j}
$$

Where $y_{i j}$ is log-odds that household $i$ in village $j$ has a "successful" response. $\beta_{0}$ is the overall intercept reflecting the log-odds that $y_{i j}$ would have a "successful" response if the independent variables or $u_{j}$ (the unobserved village effect) had no influence. $\beta_{1}$ is the effect of the observed independent variables $\mathrm{x}_{\mathrm{ij}}$ on the log-odds of $y_{i j}$ having a "successful" response after accounting for the village effect $u_{j}$. The village effect $u_{j}$ is the random effect, the variance of $u_{j}$ is the unexplained between-village variance. The random effects ordered logit model takes the following form:

$$
y_{k i j}=\alpha_{k}-\beta_{1} x_{i j}+u_{j}
$$

$y_{k i j}$ is the log-odds that household $i$ in village $j$ is likely to have a response in category $k$ or lower. $a_{k}$ is the log-odds that $y_{k i j}$ would have a response in category $k$ or lower if the independent variables or $u_{j}$ (the unobserved village effect) had no influence. $\beta_{1}$ is the effect of the observed independent variables on the log-odds of $y_{k i j}$ having a response in category $k$ or lower after accounting for the village effect $u_{j}$ and holding other independent variables constant.

Semistructured interviews (lasting an hour) were completed with 53 rice farmers in the 10 sample villages. The number of rice farmers interviewed per village ranged from three to six. Issues emerging in early interviews were followed up in subsequent interviews to gauge the extent to which they were generic to farmers in the region or specific to a household. This approach to the semistructured interviews recognizes that a household's resilience and ability to access assets to cope with climate hazards are embedded within the structures and contexts of their day-to-day lives (Wisner et al. 2004). An extensive field diary was kept documenting contextual factors for each of the 10 villages. This served as a useful validation tool for analysis of the semistructured interviews with farmers.

Interviews were undertaken with officials in the disaster management and agricultural sectors at the State, District, and Block $^{[3]}$ levels prior to conducting primary research in the villages in order to provide context for the pilot household survey. They 
Table 4. The effect (coefficient) of household asset levels, socioeconomic standing, access to institutional support, and partaking in other livelihood strategies on a household's probability of suffering greater crop loss following the 2008 floods or cyclone Phailin and the probability to take longer to recover pre-2008 flood rice cropping levels.

\begin{tabular}{|c|c|c|c|}
\hline & $\begin{array}{l}2008 \text { floods } \\
\text { crop loss }\end{array}$ & $\begin{array}{l}2008 \text { floods recovery time } \\
\text { was two years or more }\end{array}$ & $\begin{array}{l}\text { Cyclone Phailin } \\
\text { crop loss }\end{array}$ \\
\hline \multicolumn{4}{|l|}{ Household assets } \\
\hline Land owning household & $\begin{array}{l}-0.3486 \\
(0.3403)\end{array}$ & $\begin{array}{l}-0.5529 \\
(0.3569)\end{array}$ & $\begin{array}{c}0.2956 \\
(0.3309)\end{array}$ \\
\hline Total area of land cultivated by household & $\begin{array}{l}-0.0103 \\
(0.0718)\end{array}$ & $\begin{array}{c}0.1851^{* *} \\
(0.0857)\end{array}$ & $\begin{array}{c}-0.1687 * * \\
(0.0821)\end{array}$ \\
\hline Livestock owned by household & $\begin{array}{l}-0.0337 \\
(0.3140)\end{array}$ & $\begin{array}{l}-0.4460 \\
(0.3386)\end{array}$ & $\begin{array}{l}-0.3225 \\
(0.3149)\end{array}$ \\
\hline Fruit tree owned by household & $\begin{array}{l}-0.5206^{*} \\
(0.3007)\end{array}$ & $\begin{array}{l}-0.4597 \\
(0.3045)\end{array}$ & $\begin{array}{c}0.1787 \\
(0.2969)\end{array}$ \\
\hline \multicolumn{4}{|l|}{ Socioeconomic standing } \\
\hline Scheduled caste and scheduled tribe & $\begin{array}{l}1.3183 * * \\
(0.4637)\end{array}$ & $\begin{array}{l}-0.3381 \\
(0.3843)\end{array}$ & $\begin{array}{l}1.2237 * * \\
(0.4054)\end{array}$ \\
\hline \multicolumn{4}{|l|}{ Institutional Support } \\
\hline Below Poverty Line card holder in household & $\begin{array}{c}0.1368 \\
(0.2765)\end{array}$ & $\begin{array}{c}0.3804 \\
(0.2859)\end{array}$ & $\begin{array}{l}-0.1244 \\
(0.2747)\end{array}$ \\
\hline \multicolumn{4}{|l|}{ Other livelihood strategies } \\
\hline Household sells livestock & $\begin{array}{c}0.0196 \\
(0.3392)\end{array}$ & $\begin{array}{c}0.0285 \\
(0.3367)\end{array}$ & $\begin{array}{c}0.1256 \\
(0.3310)\end{array}$ \\
\hline Household sells fruit & $\begin{array}{c}-0.8167^{* *} \\
(0.3995)\end{array}$ & $\begin{array}{l}-0.813^{*} \\
(0.4316)\end{array}$ & $\begin{array}{l}-0.3253 \\
(0.4091)\end{array}$ \\
\hline Household member in formal employment ${ }^{t}$ & $\begin{array}{l}0.6699 * * \\
(0.3016)\end{array}$ & $\begin{array}{l}-0.4454 \\
(0.3068)\end{array}$ & $\begin{array}{l}-0.1379 \\
(0.2940)\end{array}$ \\
\hline Household member is a laborer & $\begin{array}{l}0.8273 * * \\
(0.3497)\end{array}$ & $\begin{array}{l}-0.0311 \\
(0.3517)\end{array}$ & $\begin{array}{c}0.3216 \\
(0.3370)\end{array}$ \\
\hline Household member has migrated & $\begin{array}{l}-0.4412 \\
(0.2939) \\
\end{array}$ & $\begin{array}{c}0.0064 \\
(0.3044) \\
\end{array}$ & $\begin{array}{l}-0.0853 \\
(0.2909) \\
\end{array}$ \\
\hline \multicolumn{4}{|c|}{$\begin{array}{l}* p<0.1 ; * * p<0.05 ; \text { Standard errors in parentheses. } \\
{ }^{*} \text { and }{ }^{8} \text { Refers to coefficients estimated using random effects ordered logit models. Here, a negative coefficient implies that a lower amount of crop loss } \\
\text { was sustained by the hazard event. } \\
\text { tRefers to the coefficient representing the influence of a given variable on the probability a household took two or more years to recover rice cropping } \\
\text { to pre-2008 levels. This was estimated using a random effects binary logit model. Here, a negative coefficient implies that a household took less than } \\
\text { two years to recover following the } 2008 \text { floods. } \\
\text { 'Refers to a member of the household in government employment or private sector employment. } \\
\text { "Refers to a member of the household currently in permanent or temporary migration. }\end{array}$} \\
\hline
\end{tabular}

enable accumulation and sale of surplus production, thereby restricting the flow of investment in farm improvement (Eriksen and Silva 2009).

\section{Impact of climate hazards on rice cropping}

The majority of the rice farmers surveyed experienced either total crop loss or crop losses greater than 50\% during the 2008 floods (Fig. 2a), and during cyclone Phailin in 2013 (Fig. 2b). The sensitivity of rice farmers to crop losses is corroborated by Government of Odisha statistics ${ }^{[6]}$. Within our sample, $56 \%$ of households took two years or more to recover rice cropping to pre-2008 flood levels indicating the longer term damage to rice farming following climate hazards. If a household sells fruit it reduces the odds that rice cropping took two or more years to recover after the 2008 floods ( $p<0.1$; Table 4).

\section{Rice farmers' coping strategies}

Following climate hazard shocks to rice cropping, farmers undertook an array of coping strategies. Following Maxwell (1996) we classified coping strategies as those that do not enable accumulation of assets, preclude investment, or inhibit transformation of existing structural constraints to rice cropping (Maxwell 1996). Coping strategies are used when normal livelihood function supported by rice farming is not possible. The following coping strategies are used during cropping seasons that are not impacted by climate hazards: accessing the Targeted Public Distribution System (TPDS) ${ }^{[7]}$, selling household assets, migration, daily wage labor, and loan taking. These coping strategies are part of a low-productivity/low-income rice-based livelihood system. Following climate hazards two additional coping strategies were employed: (i) reducing levels of household food consumption and (ii) securing government relief (Table 5).

Access to food from the TPDS can compensate for shortfalls in production induced by climate hazards. Over $52 \%$ of surveyed households utilize Below Poverty Line (BPL) entitlements through the TPDS (see Table 5). The qualitative interviews reiterated the importance of the TPDS to support coping; this was illustrated by one rice farmer who noted that following the floods in 2008 and cyclone Phailin he would have migrated without BPL rice (SSI:10). To cope with the crop losses from the 2008 floods and cyclone Phailin some farming households sold livestock ( $22 \%$ and $17 \%$, respectively) or other assets $(18 \%$ and $12 \%$, respectively) including land, gold, or harvested crops (Table 5 ). The ability to sell fruit reduces the odds of experiencing more severe flood impacts $(p<0.05$; Table 4$)$. 
Fig. 2. (a) Rice crop losses reported by households following the 2008 floods (N/A refers to households not cultivating rice in 2008) and (b) rice crop losses reported by households following cyclone Phailin in 2013.

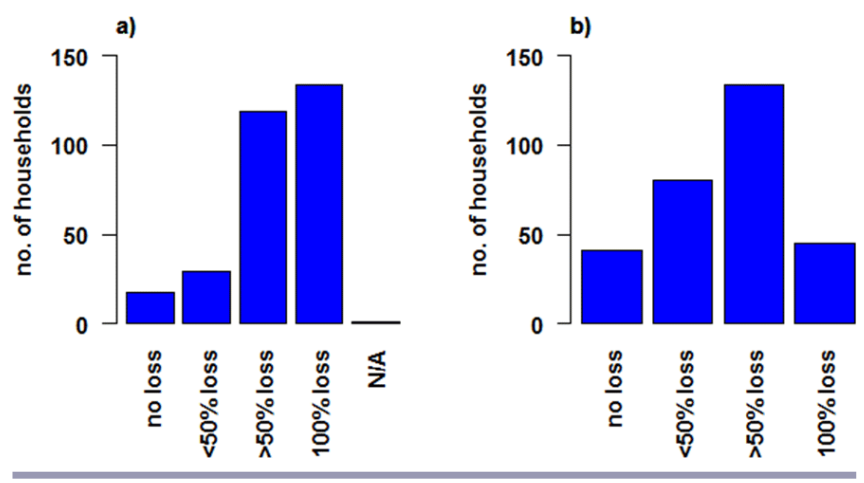

Table 5. Coping strategies employed by households following rice crop loss after the 2008 floods and cyclone Phailin. (Each cell represented as proportion of all households [ $\mathrm{N}=300])$.

\begin{tabular}{lcc}
\hline \hline Coping Strategy & $\begin{array}{c}\text { 2008 Floods } \\
(\%)\end{array}$ & $\begin{array}{c}\text { Cyclone } \\
\text { Phailin }(\%)\end{array}$ \\
\hline Government relief & 46.33 & 22.67 \\
Reduced food sold to markets & 3.00 & 3.67 \\
Reduced household consumption & 33.67 & 34.33 \\
Borrowed from friends and relatives & 65.67 & 58.00 \\
NGO assistance & 2.67 & 0.00 \\
Self-help group assistance & 8.00 & 9.33 \\
Loan & 18.33 & 13.67 \\
Crop insurance & 2.33 & 2.00 \\
Mortgaged land & 3.67 & 3.33 \\
Sold livestock & 21.67 & 16.67 \\
Sold other household assets & 17.67 & 12.33 \\
Head of household migrated & 3.67 & 2.00 \\
(permanent) & & \\
Head of household migrated & 1.67 & 1.33 \\
(temporary) & & \\
Other household members migrated & 16.33 & 20.67 \\
(permanent) & & \\
Other household members migrated & 2.00 & 4.33 \\
(temporary) & & \\
Diversified household livelihood & 9.00 & 7.00 \\
activities & & \\
Daily wage labor & 65.00 & 57.00 \\
Below Poverty Line - Targeted Public & 52.67 & 52.67 \\
Distribution System & & \\
Other & 30.00 & 32.33 \\
Did not need to cope - could carry on & 8.33 & 19.33 \\
as usual & & \\
\hline
\end{tabular}

Households often resort to wage labor when there is a shortage of food from their fields to meet other costs or to pay off loans. In normal times, one in four $(24 \%)$ households use wage labor income to fund costs of rice cultivation (Table 6). Following crop losses in the 2008 floods, nearly two out of three households $(65 \%)$ used wage labor to cope; $57 \%$ used wage labor after Cyclone Phailin (Table 5). This form of coping is contingent upon available work. Low wages, the irregularity of work, and the immediacy of expenditure needs rarely allow for accumulation of savings or assets through this coping method. A sharecropper who also does daily wage labor mixing cement, noted how work was not always available throughout the year and did not cover costs of living (SSI:8). Further, households reported that the Mahatma Gandhi National Rural Employment Guarantee Scheme (NREGS), which should provide guaranteed income from wage labor, was functioning poorly with scarce availability of work.

Table 6. Sources of funding used by households to pay for costs of cultivation. (Each cell represented as proportion of all households $[\mathrm{N}=300]$ ).

\begin{tabular}{lc}
\hline \hline Source of funding & $\begin{array}{c}\text { Proportion of Households } \\
(\%)\end{array}$ \\
\hline Loans from family and kin & 26 \\
Loans from money lenders & 37 \\
Loans from self-help groups & 8 \\
Loans from banks & 6 \\
Loans from co-operatives & 42 \\
Mortgaging land & 5 \\
Daily wage labor & 24 \\
Other & 60 \\
\hline
\end{tabular}

Many farming households rely on loans to fund the costs of cropping. The most common source of loans were from cooperative societies followed by loans from private moneylenders and family; less than $10 \%$ of households took loans from banks or self-help groups (Table 6). Climate hazards further intensified difficult financial situations. In the 2008 floods $18 \%$ of households used loans and $66 \%$ of households borrowed from friends and family to cope with crop losses with similar patterns reported after cyclone Phailin (Table 5). The frequency of climate induced crop losses meant that farmers are not able to repay existing loans or are forced to borrow more to compensate for lost harvests. A household commented how they had taken a loan to fund cropping in 2014, but crops were lost because of flooding and even after using remittances to repay some of the loan, an outstanding balance remained (SSI:23).

Around one in four households (just less than 25\%) used migration (permanent and/or temporary) as a strategy to cope with rice crop losses following the 2008 floods or Cyclone Phailin (Table 5). The most prevalent type was permanent migration by someone other than the household head $(16 \%$ of households after flood, 21\% after Phailin). Qualitative interviews suggested that the perceived success of the migration, as a coping strategy, appears related to skills of the migrant. High-skilled migrants, such as lecturers or teachers, better supported the sending households, who were then able to cope better with hazard impacts by using wealth saved from remittances or obtaining responsive emergency remittances ${ }^{[8]}$. More often migrants were engaged in low-skilled labor and remittances were of a lower magnitude. For the majority of households, where migrants were engaged in unskilled labor, the migration event did little to alleviate the household's vulnerability to climate hazards and ensuing consumption volatility ${ }^{[9]}$.

\section{Rice farmer resilience: contextual drivers}

The results presented above illustrate that the majority of rice farmers have limited resilience to climate hazards; they persist in 
a livelihood system typified by low-productivity rice cropping and ineffective coping strategies. These livelihoods are susceptible to losses from climate hazards and do not generate resources that farmers can utilize in response to climate impacts. This is a partial explanation as to why rice farmers lack resilience; it does not answer what led to this state occurring nor fully explain why it persists. To understand why such a state persists it is necessary to identify the underlying contextual drivers of this situation. We identified four key underlying contextual drivers that generate institutional, social, cultural, and economic feedbacks that reinforce this vulnerable state of rice farming. Our research suggested that these underlying contextual drivers were (i) the institutions surrounding land ownership, (ii) the nature of formal institutional support, (iii) lack of employment diversity, and (iv) expenses related to cultural activities.

\section{Land ownership and size of land holdings}

The median area of land owned by the households surveyed was 0.8 hectares (ha), with a mean of 1.2 ha, and the median total area of land cultivated by households, i.e., including land cultivated by sharecroppers, was 2 ha (mean $=2.3 \mathrm{ha}$ ). Larger land holdings increased the odds of rice harvests meeting household needs for a longer period of time and of needing to use lower proportions for household consumption $(p<0.05$; Table 3 ). These results demonstrate the importance of adequate land access in enabling rice farming to meet household needs.

Of the surveyed households, $57 \%$ held plots under sharecropping arrangements, whereby a farmer worked another person's land, in exchange for either a small fee or a proportion of the crops produced. Sharecropping almost without exception prevented the farmer from investing in land, farming resources, crops, or tools. One sharecropping household commented that the landowners do not invest any money in the land (SSI:10) and another sharecropper stated that he approached the land owner about sharecropping arrangements because the land had been idle for seven years with the landowner now contributing half the cost of pesticides (SSI:20). In some cases sharecroppers also change plots at frequent intervals; for example, one sharecropper cultivates land away from his village and changes plot every year (SSI:22). Lack of land ownership and small areas of land ownership act as feedback mechanisms that impede post disaster resilience.

\section{Formal institutional support}

Local governance institutions, which include the relevant offices of the agricultural department, the Block office, and the village level administration, known as Panchayati Raj, often do not function in accordance with the needs of rice farmers, especially the poorest. In some villages irrigation canals were not maintained leaving farmers vulnerable to crop losses (due to moisture shortages). Seeds were not always available at the Block offices ${ }^{[10]}$ or co-operatives in time for planting; this meant farmers used lower yielding traditional seeds or seeds purchased in private markets. Furthermore, awareness of when seeds were available at the Block was communicated through social networks, i.e., larger, well-endowed farmers with Block level contacts would find out inputs had arrived at the Block agricultural office and news would be distributed via their networks. There was not equal awareness amongst farmers of the availability of inputs at the Block office.

The distribution of resources from the Block level worked against small-scale farmers. The storm surge in the 1999 super cyclone increased the salinity of many coastal fields; in response the government distributed gypsum to farmers from the Block offices. However, traveling to the Block office created significant transaction costs both in terms of lost time, which could otherwise be spent earning an income, and through funding travel. For these reasons farmers were unwilling to visit the Block office or transport gypsum to their fields (interview with Block level agricultural officer). Another farmer noted that he buys seeds in the private market because the Block is too far away (SSI:17), though many farmers were accessing seeds locally through cooperatives. These examples illustrate how a combination of institutional management of inputs and local geography impedes some farmers' access to resources that support rice cropping and recovery of cultivation following climate hazards.

The nature of agricultural extension meant many small-scale farmers were excluded from knowledge and skill transfers. Only $13 \%$ of households have attended training or demonstrations. It was reported that training and demonstrations were attended by, "or for," larger farmers. A small-scale rice farmer noted that training took place "yesterday" but only farmers "with more land" go (SSI:27). This reflects the agricultural department policy of strategically targeting a handful of progressive farmers in each panchayat. A pattern emerges whereby there was unequal access to agricultural extension, which worked against the small-scale cultivators. Thus, small-scale farmers relied on rice cropping with low yields, neither accruing resources to cope with shocks or external knowledge to adapt or enhance cultivation practices.

\section{Employment diversity}

A lack of suitable alternative livelihood strategies left many rice farmers in a situation whereby they relied on cultivating yet remained vulnerable to recurrent climate hazards. Seventy-four percent of households undertook daily wage labor or diversified livelihood strategies to compensate for crop losses following natural hazards (Table 5). However, wage labor did not serve as a springboard for households to invest in rice cropping. Only $35 \%$ of households were able to supplement rice farming via regular public or private sector employment.

\section{Expenses related to cultural activities}

Households struggling to access food via rice farming strategies remained saddled with other income stresses. These could be large significant events such as weddings or repeat small-scale household expenditures, e.g., for medicine. Weddings presented households with substantial costs, but because of their cultural importance farmers often prioritized saving income for this endeavor. As a result, scarce financial resources were not invested into enhancing returns from rice farming. For example, one farmer interviewed could not afford fertilizer for the 2014 main monsoon rice growing season (kharif season) because of paying for his daughter's wedding, with predictions of lower yields and shortage of food later in the year (SSI:13). The costs of weddings often exceeded rice farmers' financial capabilities, resulting in loan taking or sales of land. The knock-on effect is reduced investment in rice cropping, increased loan taking, or asset sales serving to reduce rice cropping households' long-term climate resilience.

\section{DISCUSSION}

The mechanisms through which climate hazards have short- and long-term impacts on farmers are well understood. These 
mechanisms include damage to crops, livestock, and productive farm assets, (Carter et al. 2007, Eriksen and Silva 2009, Thornton et al. 2009, Lobell et al. 2011, Barrett and Santos 2014, Silva and Matyas 2014, Birthal et al. 2015) and also influencing behavior where farmers adopt low-risk but low-return agricultural technologies or alter investment in human capital (Dercon and Christiaensen 2011, Mottaleb et al. 2013). In the Mahanadi Delta, climate hazards cause rice production losses which is problematic because rice is used for household consumption and there is an absence of insurance, reliable off-farm income, and formal credit. These results emphasize that climate hazards can have long-term adverse effects on farming and rural livelihoods.

Rice farming is precarious; it does not generate resources to allow farmers to effectively respond to climate hazards and necessitates a range of coping strategies to sustain livelihoods. Climate hazards, such as the floods in 2008 and Cyclone Phailin interact with this livelihood-farming system to amplify vulnerabilities and limit opportunities for improved rice cropping. For example, many farmers are dependent upon loans to support subsistence rice farming, and rice farming does not generate returns to pay back loans. To be able to repay loans, to obtain credit for the following season, households often sold small portions of their harvest, which was already insufficient, used remittances if available, or sought daily wage labor ${ }^{[11]}$. Remittances did not provide an income flow to stimulate growth of climate resilient and productive rice cropping. Remittances from high-skilled migrants were rarely invested to increase returns from rice cropping but more often spent on building large concrete ( $p u k k a$ ) homes. Remittances from low-skilled migrants were not of sufficient quantity to facilitate investment to boost rice cropping; these remittances just covered immediate household needs in normal times.

These experiences resonate with Béné et al. (2016a) who argue that a conceptual model of hazard response and recovery is too simplistic in poor rural areas because it does not fully capture that rural households live in a constant state of recovery and coping. Vulnerability analyses draw attention to the fact that households face multiple interacting stressors and their response capacity is constrained by this (O'Brien and Leichenko 2000, Eriksen and Silva 2009). Yet this understanding is not fully integrated into our implementation of disaster risk reduction or resilience building. Conceptual models of resilience need to reflect the interaction between climate hazards, the cyclical nature of low-productivity rice cropping, and the constant state of coping. Simply put, interventions that seek to make rice cropping less sensitive to climate hazards may not build resilience if they do not recognize the broader multistress, low-productivity state of rice farming. In parallel, development-focused interventions seeking to redress the subsistence level of rice-based livelihoods need to take into account how climate hazards amplify an already challenging environment. The need to integrate climate adaptation into disaster risk reduction and international development practice to improve resilience has long been articulated (Boyd et al. 2008). Yet our findings from the Mahanadi show that practical means of delivering this change are not yet evident.

Although the coping strategies undertaken by rice farmers partly contribute to the persistence of vulnerability, e.g., through depletion of assets, increases in, or maintenance of, debt, they do not fully explain why vulnerability occurs or persists. These coping strategies can be seen as symptoms of the absence of resilience; ultimately a range of contextual factors interact to maintain this low-productivity, low-resilience state of rice farming. These contextual factors undermine resilience in myriad ways often reinforcing low-return rice cropping that precludes wealth generation, necessitates coping, and does not provide farmers with resources to respond adequately to climate shocks. For example, the institutions governing land access mean many households operate small plots that do not generate sufficient returns because there is no surplus to sell. Thus small and insecure land holdings act as a break on income accrual and asset accumulation that can be used to smooth the impact of crop losses following climate hazards.

Formal institutional support from the local government does not align with the needs, capacities, or context of small-scale rice farmers. There are reinforcing links between contextual factors such as limited access to land and government support, that serves to undermine rice farming and keep farmers in a vulnerable state. This is illustrated by sharecroppers who reported difficulties in accessing loans and government schemes to support agriculture without a certificate of land ownership (a patta). In contrast to sharecroppers, farmers who owned land were more likely to fund cultivation via formal credit (co-operatives) while also having a higher probability of not using money lenders (informal) or daily wage laboring ( $p<0.05$; Table 7). This was despite agricultural credit from the Kisan Credit Card (KCC) being available to sharecroppers (Ministry of Agriculture 2014c). The qualitative interviews emphasized the marginalization of small-scale famers from formal institutional support. This meant a large proportion of sharecroppers were not aware of the insurance components available within the KCC, which would otherwise be an ex-post means of coping with production shocks.

Table 7. The effect (coefficient) of land ownership on the probability of farmers funding costs of cultivation from different sources.

\begin{tabular}{lc}
\hline \hline Source of funding & Coefficient $^{\dagger}$ \\
\hline Loans from family and kin & 0.218 \\
& $(0.347)$ \\
Loans from money lenders & $-0.746^{* *}$ \\
& $(0.362)$ \\
Loans from co-operatives & $1.317^{* *}$ \\
& $(0.342)$ \\
Daily wage labour & $-1.313^{* *}$ \\
& $(0.340)$ \\
Other & -0.283 \\
& $(0.318)$ \\
\hline${ }^{\dagger}$ Refers to coefficients estimated from a random effects binary logit \\
model whereby land ownership is the predictor variable and the source \\
of funding is a binary response variable. \\
$* * 00.05$; Standard errors in parentheses.
\end{tabular}

On-farm and off-farm activities can be complementary in assisting households to manage risk. In other contexts off-farm income has been important in helping small-scale farmers cope with shocks in India (Gaurav 2015), Mozambique (Cunguara et al. 2011), and South America (Bebbington 1999). In Odisha, vulnerable farming communities are characterized by dependence 
on subsistence rice farming and limited off-farm opportunities (Panda 2016). In the Mahanadi, we found that the lack of offfarm employment opportunities is a constraint for rice farmers. Without viable, alternative livelihood strategies farmers rely on rice cropping and a mix of different coping strategies despite the persistent vulnerability of rice cropping to climate hazards. Rice cropping in the Mahanadi Delta occurs in an economic environment with few options available to generate income for investment into farming. With limited use of remittances reinvested into rice farming and a lack of suitable local government support to enhance farming activities, resilience is further undermined. This exemplifies how a set of underlying contextual factors work together to keep rice cultivation in a lowlevel state that is sensitive to climate impacts, does not generate the resources farmers need to respond to future climate impacts, and requires farmers to engage in coping activities to sustain livelihoods.

Investigations have been made into the use of resilience as a concept to guide development. These studies have focused on the following: identifying which economic units are or are not resilient; the differential impacts of shocks on these units; and the responses of different economic units to these shocks (Hoddinott 2006, Carter et al. 2007, Akter and Mallick 2013, Constas et al. 2014, Alfani et al. 2015, Jain et al. 2015, Cissé and Barrett 2016). Analysis of this nature enables interventions to be targeted to increase the resistance of farmers to hazards, e.g., flood resistant seeds (Dar et al. 2013) or enable ex post coping (e.g., Akter et al. 2016). Our work builds upon the arguments of Béné et al. (2016a) and Enfors (2013) in highlighting the importance of contextual factors to explain resilience in farmers. Our analysis strongly suggests that a range of interacting contextual factors prevent the emergence of resilient, high-return rice cropping livelihoods. Agricultural interventions need to take into account these contextual factors to shift rice cropping onto a trajectory toward resilience. Our context-based analysis shows how rice cultivation and the prevailing social norms, formal institutions, and economy interact to shape coping capacity and the distribution of resilience. We argue that context based studies that explain how resilience occurs and resilience measurement studies that monitor economic units pre- and postshock are complementary. Contextbased studies can explain why differential levels of postdisaster resilience occur. Such complementary analysis will likely lead to more sustainable and effective resilience building interventions.

\section{CONCLUSIONS}

In poor, rural, deltaic regions, identifying how to make rice cultivation more resilient to shocks and stresses could improve the well-being of many millions of people. Our research in the Mahanadi Delta identified that climate hazards cause damage to rice cropping; however, these climate impacts amplify an already challenging livelihood context, where low-productivity rice cropping necessitates households to engage in a range of sometimes harmful coping activities. Low-productivity rice farming does not generate resources for expansion or development of rice farms (and associated livelihoods) or resources to respond to climate hazards. Ultimately, we argue that underlying social, economic, institutional, and environmental contextual factors, that are endemic in rice farming communities in deltas, create a state of perpetual vulnerability. At the global level the aim to make livelihoods more resilient is central to both policy and programming in disaster risk reduction and contemporary development (DFID 2011, Roberts et al. 2015, Tanner et al. 2015). Our findings have relevance for both these agendas in the context of rural delta regions. In particular we highlight that agricultural development policy seeking to make rice farming more resilient to climate hazards should identify and tackle contextual factors that maintain vulnerability. Until these contextual challenges are addressed, initiatives that seek to enhance agricultural output in hazardous locations (such as deltas) will continue to fail to deliver resilience to subsistence rice farmers whose livelihoods will continue to be undermined by the simple daily turning of the planet.

[1] "Domains of attraction" or "multiple equilibria" refer to states of system functioning that are maintained through time because of feedbacks and interactions within the system in question. Enfors and Gordon (2008) provide a useful discussion of the concept of multiple equilibria in the context of smallholder farmers responding to climate risk in sub-Saharan Africa. They suggest that multiple welfare equilibria exist and that selfreinforcing feedbacks such as low returns from assets prevent households moving to a higher welfare equilibrium.

${ }^{[2]}$ In our household survey, $74 \%$ of households operated fields that had access to surface water irrigation and $7 \%$ of households operated fields that had access to groundwater irrigation. In the qualitative data households revealed that often these channels were not operational, in a state of disrepair, and were not accessible to all plots operated by a household. Further, households faced costs in accessing this water namely through hiring water pumps.

${ }^{[3]}$ In India the organizational hierarchy broadly follows: Centre (national/all-India) $\rightarrow$ State (e.g., Odisha) $\rightarrow$ District (e.g., Jagatsinghpur) $\rightarrow$ Block $\rightarrow$ Panchayat $\rightarrow$ Villages $\rightarrow$ Wards.

${ }^{[4]}$ (SSI: $n$ ) refers to the semistructured interview ID.

[5] "Save" refers to the ability to save money.

${ }^{[6]}$ In the 2008 floods 64,994 ha of cropland were affected of which 59,994 ha ( $92 \%$ of all cropland affected) experienced crop losses greater than $50 \%$ in Kendrapara district; in Jagatsinghpur district 15,129 ha of cropland were affected of which 14,829 ha $(98 \%$ of cropland affected) experienced crop losses greater than $50 \%$ (Special Relief Commissioner 2009).

${ }^{[7]}$ At the time of data collection the TPDS allowed those living in extreme poverty to access $25 \mathrm{~kg}$ of rice per month at a price of 1 rupee (US\$0.02). Households could only access this social protection scheme if they hold a Below Poverty Line (BPL) card. ${ }^{[8]}$ For example one rice farmer, whose sons had migrated away working in skilled professions (lecturer and software engineer) sent money home when over $50 \%$ of his crops were damaged after cyclone Phailin (SSI:19).

[9] A household with a son doing factory work in Tamil Nadu reflected that they request additional remittance money as the very last option because the costs of living away are high (the migrant in Tamil Nadu has little spare income; SSI: 23).

${ }^{[10]}$ The Block office and the Block agricultural office are focal points through which the state agricultural department aims to engage farmers at the local level.

${ }^{[11]}$ This situation was typified by a rice farmer who does eight days daily wage labor work per month in another village to repay loans, while, at the same time his rice harvests, which loans are invested into, are repeatedly impacted by floods (SSI:22). 
Responses to this article can be read online at: http://www.ecologyandsociety.org/issues/responses. php/9559

\section{Acknowledgments:}

The authors wish to acknowledge the Leverhulme Trust and the EU$C A S C O$ project for providing funding which supported this research. They also wish to thank Dr Ambika Nanda, BGVS Odisha and the enumerators from Utkal University for their assistance with the fieldwork. The authors also wish to thank the anonymous reviewers whose comments were insightful and constructive and allowed us to improve the manuscript.

\section{LITERATURE CITED}

Akter, S., T. J. Krupnik, F. Rossi, and F. Khanam. 2016. The influence of gender and product design on farmers' preferences for weather-indexed crop insurance. Global Environmental Change 38:217-229. http://dx.doi.org/10.1016/j.gloenvcha.2016.03.010

Akter, S., and B. Mallick. 2013. The poverty-vulnerabilityresilience nexus: evidence from Bangladesh. Ecological Economics 96:114-124. http://dx.doi.org/10.1016/j.ecolecon.2013.10.008

Alfani, F., A. Dabalen, P. Fisker, and V. Molini. 2015. Can we measure resilience? A proposed method and evidence from countries in the Sahel. Policy Research Working Paper. World Bank, Washington, D.C., USA. http://dx.doi.org/10.1596/1813-9450-7170

Bahadur, A. V., M. Ibrahim, and T. Tanner. 2013. Characterising resilience: unpacking the concept for tackling climate change and development. Climate and Development 5(1):55-65. http://dx.doi. org/10.1080/17565529.2012.762334

Barrett, C. B., and M. A. Constas. 2014. Toward a theory of resilience for international development applications. Proceedings of the National Academy of Sciences 111(40):14625-14630. http:// dx.doi.org/10.1073/pnas.1320880111

Barrett, C. B., T. Garg, and L. McBride. 2015. Well-being dynamics and poverty traps. Annual Review of Resource Economics 8:303-327. http://dx.doi.org/10.1146/annurevresource-100815-095235

Barrett, C. B., and P. Santos. 2014. The impact of changing rainfall variability on resource-dependent wealth dynamics. Ecological Economics 105:48-54. http://dx.doi.org/10.1016/j.ecolecon.2014.05.009

Bebbington, A. 1999. Capitals and capabilities: a framework for analyzing peasant viability, rural livelihoods and poverty. World Development 27(12):2021-2044. http://dx.doi.org/10.1016/S0305-750X (99)00104-7

Béné, C., R. M. Al-Hassan, O. Amarasinghe, P. Fong, J. Ocran, E. Onumah, R. Ratuniata, T. Van Tuyen, J. A. McGregor, and D. J. Mills. 2016a. Is resilience socially constructed? Empirical evidence from Fiji, Ghana, Sri Lanka, and Vietnam. Global Environmental Change 38:153-170. http://dx.doi.org/10.1016/j. gloenvcha.2016.03.005

Béné, C., L. Evans, D. Mills, S. Ovie, A. Raji, A. Tafida, A. Kodio, F. Sinaba, P. Morand, J. Lemoalle, and N. Andrew. 2011. Testing resilience thinking in a poverty context: experience from the Niger River basin. Global Environmental Change 21(4):1173-1184. http://dx.doi.org/10.1016/j.gloenvcha.2011.07.002

Béné, C., D. Headey, L. Haddad, and K. von Grebmer. 2016b. Is resilience a useful concept in the context of food security and nutrition programmes? Some conceptual and practical considerations. Food Security 8(1):123-138. http://dx.doi. org/10.1007/s12571-015-0526-X

Béné, C., A. Newsham, M. Davies, M. Ulrichs, and R. GodfreyWood. 2014. Review article: resilience, poverty and development. Journal of International Development 26:598-623. http://dx.doi. org/10.1002/jid.2992

Béné, C., R. G. Wood, A. Newsham, and M. Davies. 2012. Resilience: new utopia or new tyranny? Reflection about the potentials and limits of the concept of resilience in relation to vulnerability reduction programmes. IDS Working Paper 2012 (405):1-61. http://dx.doi.org/10.1111/j.2040-0209.2012.00405.x

Birthal, P. S., D. S. Negi, M. T. Khan, and S. Agarwal. 2015. Is Indian agriculture becoming resilient to droughts? Evidence from rice production systems. Food Policy 56:1-12. http://dx.doi. org/10.1016/j.foodpol.2015.07.005

Boyd, E., H. Osbahr, P. J. Ericksen, E. L. Tompkins, M. C. Lemos, and F. Miller. 2008. Resilience and "climatizing" development: examples and policy implications. Development 51(3):390-396. http://dx.doi.org/10.1057/dev.2008.32

Carter, M. R., and C. B. Barrett. 2006. The economics of poverty traps and persistent poverty: an asset-based approach. Journal of Development Studies 42(2):178-199. http://dx.doi. org/10.1080/00220380500405261

Carter, M. R., P. D. Little, T. Mogues, and W. Negatu. 2007. Poverty traps and natural disasters in Ethiopia and Honduras. World Development 35(5):835-856. http://dx.doi.org/10.1016/j. worlddev.2006.09.010

Chhotray, V., and R. Few. 2012. Post-disaster recovery and ongoing vulnerability: ten years after the super-cyclone of 1999 in Orissa, India. Global Environmental Change 22(3):695-702. http://dx.doi.org/10.1016/j.gloenvcha.2012.05.001

Chhotray, V., J. Hill, R. Biswal, and S. Behera. 2013. Sociopolitical and environmental dimensions of vulnerability and recovery in coastal Odisha Critical lessons since the 1999 supercyclone.

Chu, T. H., B. W. Szuster, K. Suan-Pheng, A. M. Islmail, and A. D. Noble. 2010. Tropical deltas and coastal zones: food production, communities and environment at the land-water interface. CABI, Wallingford, UK.

Cissé, J. D. , and C. B. Barrett. 2016. Estimating development resilience: a conditional moments-based approach. Working Paper No. 236. African Development Bank, Abidjan, Côte d'Ivoire. [online] URL: https://www.afdb.org/fileadmin/uploads/afdb/ Documents/Publications/WPS No 236 Estimating Development Resilience A Conditional Moments-Based Approach.pdf

Constas, M. A., T. R. Frankenberger, J. Hoddinott, N. Mock, D. Romano, C. Béné, and D. Maxwell. 2014. A common analytical model for resilience measurement. Food Security Information Network, Rome, Italy. 
Cunguara, B., A. Langyintuo, and I. Darnhofer. 2011. The role of nonfarm income in coping with the effects of drought in southern Mozambique. Agricultural Economics 42:701-713. http://dx.doi.org/10.1111/j.1574-0862.2011.00542.x

Dar, M. H., A. de Janvry, K. Emerick, D. Raitzer, and E. Sadoulet. 2013. Flood-tolerant rice reduces yield variability and raises expected yield, differentially benefitting socially disadvantaged groups. Scientific Reports 3(3315). http://dx.doi.org/10.1038/ $\underline{\text { srep03315 }}$

Das, S. 2012. The role of natural ecosystems and socio-economic factors in the vulnerability of coastal villages to cyclone and storm surge. Natural Hazards 64(1):531-546. http://dx.doi.org/10.1007/ s11069-012-0255-9

Department for International Development (DFID). 2011. Defining disaster resilience: a DFID approach paper. DFID, London, UK.

Dercon, S., and L. Christiaensen. 2011. Consumption risk, technology adoption and poverty traps: evidence from Ethiopia. Journal of Development Economics 96(2):159-173. http://dx.doi. org/10.1016/j.jdeveco.2010.08.003

Directorate of Economics \& Statistics (DES). 2013. District wise land use statistics. New Delhi, India.

Duncan, J. M. A., J. Dash, and E. L. Tompkins. 2017. Observing adaptive capacity in Indian rice production systems. AIMS Agriculture and Food 2(2):165-182. http://dx.doi.org/10.3934/ agrfood.2017.2.165

Enfors, E. 2013. Social-ecological traps and transformations in dryland agro-ecosystems: using water system innovations to change the trajectory of development. Global Environmental Change 23(1):51-60. http://dx.doi.org/10.1016/j.gloenvcha.2012.10.007

Enfors, E. I., and L. J. Gordon. 2008. Dealing with drought: the challenge of using water system technologies to break dryland poverty traps. Global Environmental Change 18(2008):607-616. http://dx.doi.org/10.1016/j.gloenvcha.2008.07.006

Ericson, J. P., C. J. Vörösmarty, S. L. Dingman, L. G. Ward, and M. Meybeck. 2006. Effective sea-level rise and deltas: causes of change and human dimension implications. Global and Planetary Change 50(1-2):63-82. http://dx.doi.org/10.1016/j.gloplacha.2005.07.004

Eriksen, S., and J. A. Silva. 2009. The vulnerability context of a savanna area in Mozambique: household drought coping strategies and responses to economic change. Environmental Science \& Policy 12(1):33-52. http://dx.doi.org/10.1016/j. envsci.2008.10.007

Folke, C. 2006. Resilience: the emergence of a perspective for social-ecological systems analyses. Global Environmental Change 16(3):253-267. http://dx.doi.org/10.1016/j.gloenvcha.2006.04.002

Gaurav, S. 2015. Are rainfed agricultural households insured? Evidence from five villages in Vidarbha, India. World Development 66:719-736. http://dx.doi.org/10.1016/j.worlddev.2014.09.018

Giosan, L., J. Syvitski, S. Constantinescu, and J. Day. 2014. Climate change: protect the world's deltas. Nature 516 (7529):31-33. http://dx.doi.org/10.1038/516031a
Government of India. 2011. Census of India. Office of the Registrar General \& Census Commissioner, New Delhi, India. [online] URL: http://censusindia.gov.in/

Günther, I., and K. Harttgen. 2009. Estimating households vulnerability to idiosyncratic and covariate shocks: a novel method applied in Madagascar. World Development 37:1222-1234. http://dx.doi.org/10.1016/j.worlddev.2008.11.006

Hoddinott, J. 2006. Shocks and their consequences across and within households in rural Zimbabwe. Journal of Development Studies 42(2):301-321. http://dx.doi.org/10.1080/00220380500405501

Hoddinott, J., and A. R. Quisumbing. 2010. Methods for microeconometric risk and vulnerability assessments. Pages 62-100 in R. Fuentes-Nieva and P. A. Seck, editors. Risk, shocks, and human development: on the brink. Palgrave Macmillan, London, UK.

Hsiang, S. M., and A. S. Jina. 2014. The causal effect of environmental catastrophe on long-run economic growth: evidence from 6,700 cyclones. NBER Working Paper No. 20353. National Bureau of Economic Research, Cambridge, Massachusetts, USA.

Jain, M., S. Naeem, B. Orlove, V. Modi, and R. S. DeFries. 2015. Understanding the causes and consequences of differential decision-making in adaptation research: adapting to a delayed monsoon onset in Gujarat, India. Global Environmental Change 31:98-109. http://dx.doi.org/10.1016/j.gloenvcha.2014.12.008

Krishna Kumar, K., K. Rupa Kumar, R. G. Ashrit, N. R. Deshpande, and J. W. Hansen. 2004. Climate impacts on Indian agriculture. International Journal of Climatology 24(11):1375-1393. http://dx.doi.org/10.1002/joc.1081

Lobell, D. B., M. Bänziger, C. Magorokosho, and B. Vivek. 2011 Nonlinear heat effects on African maize as evidenced by historical yield trials. Nature Climate Change 1:42-45. http://dx.doi. org/10.1038/nclimate1043

Mathison, C., A. Wiltshire, A. P. Dimri, P. Falloon, D. Jacob, P. Kumar, E. Moors, J. Ridley, C. Siderius, M. Stoffel, and T. Yasunari. 2013. Regional projections of North Indian climate for adaptation studies. Science of the Total Environment 468-469(1): S4-S17. http://dx.doi.org/10.1016/j.scitotenv.2012.04.066

Maxwell, D. G. 1996. Measuring food insecurity: the frequency and severity of "coping strategies." Food Policy 21(3):291-303. http://dx.doi.org/10.1016/0306-9192(96)00005-X

Ministry of Agriculture. 2014a. All India report on number and area of operational holdings. Ministry of Agriculture, New Delhi, India.

Ministry of Agriculture. 2014b. Agricultural census. Ministry of Agriculture, New Delhi, India.

Ministry of Agriculture. 2014c. Loan facilities for short term agricultural operations. Ministry of Agriculture, New Delhi, India.

Ministry of Statistics and Programme Implementation. 2014. Millennium development goals India country report 2014. Ministry of Statistics and Programme Implementation, New Delhi, India. 
Mottaleb, K. A., S. Mohanty, H. T. K. Hoang, and R. M. Rejesus. 2013. The effects of natural disasters on farm household income and expenditures: a study on rice farmers in Bangladesh. Agricultural Systems 121:43-52. http://dx.doi.org/10.1016/j. agsy.2013.06.003

O’Brien, K. L., and R. M. Leichenko. 2000. Double exposure: assessing the impacts of climate change within the context of economic globalization. Global Environmental Change 10 (3):221-232. http://dx.doi.org/10.1016/S0959-3780(00)00021-2

Panda, A. 2016. Vulnerability to climate variability and drought among small and marginal farmers: a case study in Odisha, India. Climate and Development 1-13. http://dx.doi.org/10.1080/17565529.2016.1184606

Pritchard, B., A. Rammohan, M. Sekher, S. Parasuraman, and C. Choithani. 2013. Feeding India: livelihoods, entitlements and capabilities. Routledge, London, UK.

Roberts, E., S. Andrei, S. Huq, and L. Flint. 2015. Resilience synergies in the post-2015 development agenda. Nature Climate Change 5(12):1024-1025. http://dx.doi.org/10.1038/nclimate2776

Robinson, L. W., P. J. Ericksen, S. Chesterman, and J. S. Worden. 2015. Sustainable intensification in drylands: what resilience and vulnerability can tell us. Agricultural Systems 135:133-140. http:// dx.doi.org/10.1016/j.agsy.2015.01.005

Rufino, M. C., P. K. Thornton, S. K. Ng'ang'a, I. Mutie, P. G. Jones, M. T. Van Wijk, and M. Herrero. 2013. Transitions in agropastoralist systems of East Africa : impacts on food security and poverty. Agriculture, Ecosystems and Environment 179:215-230. http://dx.doi.org/10.1016/j.agee.2013.08.019

Sabates-Wheeler, R., and S. Devereux. 2011. Transforming livelihoods for resilient futures: how to facilitate graduation in social protection programmes. Working Paper 023. Future Agricultures Consortium, Africa.

Scheffer, M., S. Carpenter, J. A. Foley, C. Folke, and B. Walker. 2001. Catastrophic shifts in ecosystems. Nature 413 (6856):591-596. http://dx.doi.org/10.1038/35098000

Silva, J. A., and C. J. Matyas. 2014. Relating rainfall patterns to agricultural income: implications for rural development in Mozambique. Weather, Climate, and Society 6(2):218-237. http:// dx.doi.org/10.1175/WCAS-D-13-00012.1

Special Relief Commissioner. 2009. Annual Report 2008-09. Special Relief Commissioner, Bhubaneswar, India.

Tanner, T., D. Lewis, D. Wrathall, R. Bronen, N. Cradock-Henry, S. Huq, C. Lawless, R. Nawrotzki, V. Prasad, M. A. Rahman, R. Alaniz, K. King, K. McNamara, M. Nadiruzzaman, S. HenlyShepard, and F. Thomalla. 2015. Livelihood resilience in the face of climate change. Nature Climate Change 5:23-26. http://dx.doi. org/10.1038/nclimate2431

Thornton, P. K., J. van de Steeg, A. Notenbaert, and M. Herrero. 2009. The impacts of climate change on livestock and livestock systems in developing countries: a review of what we know and what we need to know. Agricultural Systems 101(3):113-127. http://dx.doi.org/10.1016/j.agsy.2009.05.002
Vörösmarty, C. J., J. Syvitski, J. Day, A. de Sherbinin, L. Giosan, and C. Paola. 2009. Battling to save the world's river deltas. Bulletin of the Atomic Scientists 65(2):31-43

Walker, B., C. S. Holling, S. Carpenter, and A. Kinzig. 2004. Resilience, adaptability and transformability in social-ecological systems. Ecology And Society 9(2):5. http://dx.doi.org/10.5751/ ES-00650-090205

Wassmann, R., N. X. Hien, C. T. Hoanh, and T. P. Tuong. 2004. Sea level rise affecting the Vietnamese Mekong Delta: water elevation in the flood season and implications for rice production. Climatic Change 66(1-2):89-107. http://dx.doi.org/10.1023/B: CLIM.0000043144.69736.b7

Wisner, B., P. Blaikie, T. Cannon, and I. Davis. 2004. At risk: natural hazards, people's vulnerability and disasters. Second Edition. Routledge, London, UK. http://dx.doi.org/10.4324/97$\underline{80203428764}$ 
Appendix 1. Household survey methodology.

Households eligible to be sampled were those engaged in rice cultivation and impacted by natural disasters in Jagatsinghpur and Kendrapara districts. The 2011 census was used as the sampling frame providing totals of cultivating households per village. To limit the sampling to villages where rice cropping has been affected by natural disasters a flood extent map over croplands during the 2008 floods was used. The flood map was generated using the Normalised Difference Flood Index (NDFI) (Boschetti et al. 2014), derived from the MODIS MOD09A1 remote sensing product (https://lpdaac.usgs.gov/products/modis products table). From this sampling frame 300 households across 10 villages were randomly sampled using the probability proportionate to size (PPS) method.

In each village 30 randomly selected households were sampled; a random start point was selected using high resolution satellite imagery in Google Earth and from this start point enumerators sampled rice farming households along a random walk. If a household was not able to respond when the enumerator visited then a time was arranged for a revisit. Also, enumerators sought to interview the member of the household with the most knowledge of rice farming practices, if he or she was not available (and would not be available during the time spent in the village), then enumerators asked questions of other household members to gauge if they had suitable knowledge of household farming practices. The timing of the questionnaire (October to December 2014) was designed to overlap with the harvest period; this minimised the possibility that key household members would be absent (e.g. seasonal migration). No households, which cultivate rice, had to be skipped or classified as non-respondent due to absence from the village. In total 300 households were sampled exceeding the sample size required to maintain a $10 \%$ margin of error at a $95 \%$ confidence level accounting for a design effect of two and a $10 \%$ no-response rate. Thus, it is a representative sample of rice farming households impacted by a recent hazard event subject to the assumptions outlined above. 
The household survey was initially formulated following outputs from semi-structured interviews with local (block and district) officials in the agriculture and disaster management sectors and a stakeholder workshop at the state level ${ }^{1}$. The questionnaire was translated from the English into Odiya (the language spoken by rice farmers in Odisha) ensuring that all rice farmers were asked the same question, with the same wording. Prior to conducting the fieldwork enumerators undertook training to gain familiarity with the questionnaire and ensure consistent understanding of terminology used. The survey was piloted to finalise question wording, this was to ensure that farmers interpreted questions as meant, and that a comprehensive list of response options were included in the questionnaire.

The questionnaire obtained ethical clearance from the University of Southampton, and was conducted anonymously; the respondents' names were not recorded. Prior to conducting the interview the respondents were given an information sheet outlining the aims of the research and how the data will be used (translated into Odiya) and they gave their consent to the enumerator.

\section{LITERATURE CITED}

Boschetti, M., F. Nutini, G. Manfron, P. A. Brivio, and A. Nelson. 2014. Comparative analysis of normalised difference spectral indices derived from MODIS for detecting surface water in flooded rice cropping systems. PloS one 9(2):e88741.

\footnotetext{
${ }^{1}$ In India the organisational hierarchy broadly follows: Centre (national/all-India) $\rightarrow$ State (e.g. Odisha) $\rightarrow$ District (e.g. Jagatsinghpur) $\rightarrow$ Block $\rightarrow$ Panchayat $\rightarrow$ Villages $\rightarrow$ Wards.
} 